\title{
IRRIGATION DEFICIT STRATEGIES ON PHYSIOLOGICAL AND PRODUCTIVE PARAMETERS OF 'TOMMY ATKINS' MANGO'
}

\author{
MARCELO ROCHA DOS SANTOS ${ }^{2 *}$, SÉRGIO LUIZ RODRIGUES DONATO ${ }^{2}$, EUGÊNIO FERREIRA COELHO ${ }^{3}$, \\ PAULO ROBERTO FERNANDES COTRIM JUNIOR ${ }^{2}$, IGOR NOGUEIRA DE CASTRO ${ }^{2}$
}

\begin{abstract}
The objective of this work was to evaluate the gas exchange, leaf temperature, yield and water use efficiency in 'Tommy Atkins' mango under irrigation deficit strategies. The experimental design was randomized block, with seven treatments with regulated deficit irrigation (RDI) under micro-spray and five treatments with partial root-zone drying (PRD) under drip irrigation. The treatments on RDI consisted of application of 100, 75 and $50 \%$ of ETc at the stages S1 (beginning of flowering to fruit set) S2 (fruit development) and S3 (fruit physiological maturation). The treatments on PRD consisted of application of 100, 80,60 and $40 \%$ of ETc, in the same three stages, alternating the irrigation side every 15 days. The regulated deficit irrigation causes less negative interference in gas exchange than the partial root-zone drying, and the climate factors affect the gas exchange and leaf temperature of 'Tommy Atkins' mango more than the regulated deficit irrigation. The partial root-zone drying irrigation with 60 and $40 \%$ of ETc causes a decrease in the 'Tommy Atkins' mango yield. The regulated deficit irrigation up to $50 \%$ of ETc, applied at the fruit maturation stage, maintain the yield and water use efficiency.
\end{abstract}

Keywords: Water deficit. Irrigation management. Mangifera indica. Gas exchange.

\section{PARÂMETROS FISIOLÓGICOS E PRODUTIVOS EM MANGUEIRAS 'TOMMY ATKINS' SOB ESTRATÉGIAS DE DÉFICIT DE IRRIGAÇÃO}

RESUMO - Objetivou-se com este trabalho avaliar as trocas gasosas, temperatura foliar, produtividade e eficiência de uso da água em mangueira 'Tommy Atkins' sob irrigação com déficit. O delineamento experimental foi em bloco casualizado, com sete tratamentos para a irrigação com déficit controlado (RDI) sob microaspersão e com cinco tratamentos para a irrigação lateralmente alternada (PRD) sob gotejamento. No manejo RDI os tratamentos consistiram da aplicação de 100, 75 e 50\% da ETc nas fases F1 (início da floração até o pegamento dos frutos), F2 (desenvolvimento do fruto), e F3 (maturação físiológica do fruto). No manejo pelo PRD os tratamentos consistiram da aplicação de 100, 80, 60 e 40\% da ETc nas três fases com alternância do lado irrigado de 15 dias. Verificou-se que a irrigação com déficit controlado causa menos interferências negativas nas trocas gasosas que a irrigação lateralmente alternada e as trocas gasosas e temperatura foliar da mangueira 'Tommy Atkins' sofrem maiores influências de elementos do clima que da irrigação com déficit controlado. A irrigação lateralmente alternada com 60 e 40\% da ETc ocasiona queda na produção da mangueira 'Tommy Atkins'. Irrigação com déficit controlado com até $50 \%$ da ETc aplicados na fase de maturação do fruto mantem a produtividade e a eficiência de uso da água.

Palavras-chaves: Déficit hídrico. Manejo da irrigação. Mangifera indica. Trocas gasosas.

\footnotetext{
*Corresponding author

${ }^{1}$ Received for publication in $03 / 05 / 2015$; accepted in $01 / 22 / 2016$.

This work was funded by FAPESB.

${ }^{2}$ Agriculture Sector, Instituto Federal Baiano Campus Guanambi, Guanambi, BA, Brazil; marcelo.rocha@guanambi.ifbaiano.edu.br, sergio.donato@guanambi.ifbaiano.edu.br, paulocotrim31@hotmail.com, igornogueira-ig@hotmail.br.

${ }^{3}$ Embrapa Mandioca e Fruticultura, Cruz das Almas, BA, Brazil; eugenio.coelho@embrapa.br.
} 


\section{INTRODUCTION}

Mango (Mangifera indica) is an important crop in Brazil, with a production exceeding 1.1 million tons in 2012. The Brazilian Northeast region accounting for $66.54 \%$ of this production, where the State of Bahia has the largest mango production with $54 \%$ of the Northeast production (IBGE, 2014). One of the factors that limit the mango production is the rainfall scarcity or irregularity, requiring irrigation. Regardless of the climate pattern in the crop areas, there are discussions on predominance of climate extremes and changes, suggesting increasing drought and heat stresses on plant. This situation may become worse if the catastrophic climate conditions predicted by the Intergovernmental Panel on Climate Change (IPCC) were confirmed (IPCC, 2000). Therefore, due to the limited availability of water, irrigation with precision and high water use efficiency (WUE) is essential, requiring deficit irrigation strategies in order to not compromise production. The regulated deficit irrigation (RDI) and partial root-zone drying (PRD) or controlled alternate partial root-zone irrigation, are among the deficit irrigation techniques that has increasing water use efficiency in some crops. (BASSOI et al., 2011; ROMERO-CONDE et al., 2014; SAMPAIO et al., 2014; GHRAB et al., 2014).

The RDI is an irrigation management that consists in inducing water deficits to plants at developmental stages, in which the fruit growth and quality have low sensitivity to water stress, not hinder its potential productivity, in order to increase water use efficiency. The PRD irrigation, also known in Brazil as controlled alternate partial root-zone irrigation, consists in alternating the side of the plant that receive irrigation every 10 to 21 days, at the phenological stage of fruit set to the harvest. The use of these strategies is based on the fact that the water deficit in the soil induce the production of the hormone abscisic acid (ABA) by the roots, which translocates through the vascular axis, concentrating on the shoot, promoting partial closing of the stomata and the control of vegetative growth, consequently reducing the water lost to the atmosphere. McCarthy et al. (2000) points out that the PRD is based on biochemical responses of plants to achieve a balance between vegetative and reproductive development through water stress, as a result, there is a significant improvement in production per unit of irrigation water applied. The irrigation should be performed before the water availability in the soil is reduced to levels that alter the metabolism of the plant to ensure the crop production (Oliveira et al., 2011). The use of different irrigation strategies and systems cause changes in soil water conditions that, associated with the climate, may influence the plant water status, with variations in leaf temperature and gas exchange, which directly influence growth, development and crop production.

Santos et al. (2013) reported that the total controlled deficit or with $50 \%$ of ETc in some stage of the 'Tommy Atkins' mango production cause a reduction in photosynthesis, transpiration and stomatal conductance. The partial water deficit caused no effect on $\mathrm{CO}_{2}$ internal concentration and leaf temperature. These authors found that the deficit induced at the flowering to fruit set stages causes a reduction in yield, which may be related to the decrease in photosynthesis, transpiration and stomatal conductance.

A study on the effects of PRD and RDI on papaya plants, Lima et al. (2015) found that the stomatal closure was induced by PRD more than by RDI, using the same soil water tension, due to the influence of the non-irrigated part of the root-zone, where the water stress induces higher abscisic acid production (LIMA et al., 2015).

The objective of the present work was to evaluate the gas exchange, leaf temperature, yield and water use efficiency of 'Tommy Atkins' mango under deficit irrigation.

\section{MATERIAL AND METHODS}

The experiments were conduct in an orchard of 'Tommy Atkins' mango (Mangifera indica L.) of 18 years old, with plants spaced $10 \times 8 \mathrm{~m}$, located in the Irrigated Perimeter of Ceraima, in Guanambi, Southwestern State of Bahia, Brazil (14 ${ }^{\circ} 17^{\prime} 03^{\prime \prime S}, 42^{\circ}$ $43^{\prime} 57^{\prime \prime} \mathrm{W}$ and altitude of $530 \mathrm{~m}$ ). The soil of the experimental area was classified as Typical Eutrophic Ta Fluvic Neosol (EMBRAPA, 2013). According to the Köppen classification, the climate is Aw: hot and dry semi-arid, with average temperature of $25.6^{\circ} \mathrm{C}$, annual average precipitation of $680 \mathrm{~mm}$, and concentrated rainy season between November and March. Climatic variables were collected from an automatic weather station, about 800 meters from the experimental area during the experiments, as presented in Figure 1.

Two experiments, one with water management by the PRD method and another with by the RDI method, were implemented in a commercial area of the Irrigated Perimeter of Ceraima in January 2014. The water used for irrigation presented electrical conductivity of $1.0 \mathrm{dS} \mathrm{m}^{-1}$ and was obtained from a tubular well. The application was performed in the experimental units through a drip irrigation system with nine pressure compensating drips with flow of $8 \mathrm{~L} \mathrm{~h}^{-1}$ for each side of each plant (PRD), and through a microspray system with 2 emitters with flow of $100 \mathrm{~L} \mathrm{~h}^{-1}$ per plant and pressure $200 \mathrm{kPa}$ (RDI). The mango production techniques employed in the studied region were considered during the production cycle. 

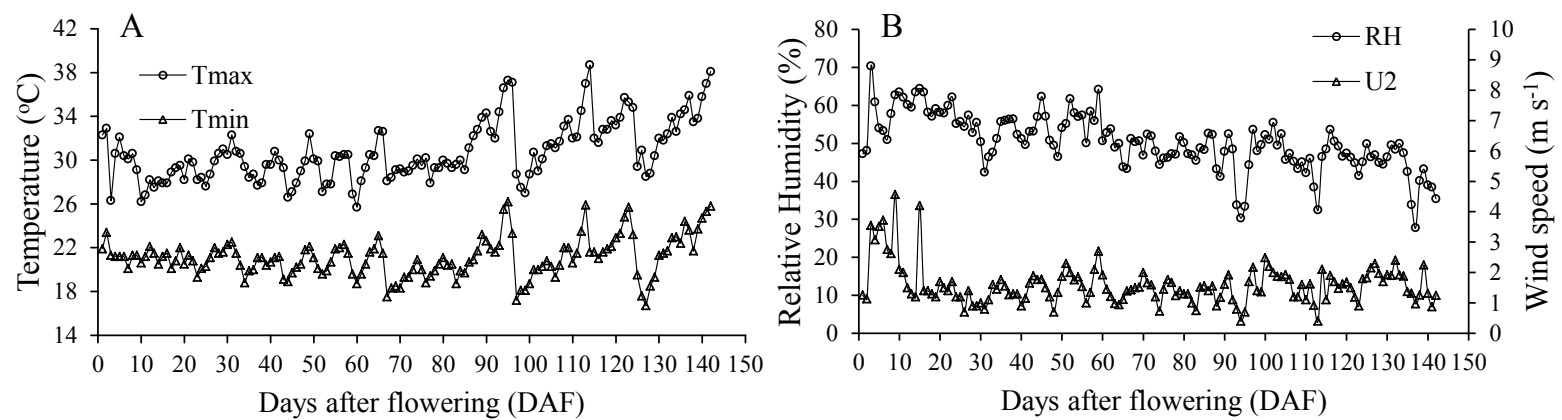

Figure 1. Maximum temperature (Tmax) and minimum temperature (Tmin) (A), air relative humidity $(\mathrm{RH})$, average wind speed (U2) (B), during the experimental period (06/01/2014 to 10/21/2014).

The plants were pruned for cleaning the top and central openings (EMBRAPA, 2004), and fertilized with $350 \mathrm{~g}$ of MAP (monoammonium phosphate; $\left.\mathrm{NH}_{4} \mathrm{H}_{2} \mathrm{PO}_{4} ; 48 \% \mathrm{P}_{2} \mathrm{O}_{5} ; 10 \% \mathrm{~N}\right), 250 \mathrm{~g}$ of potassium chloride $\left(\mathrm{KCl} ; 58 \% \mathrm{~K}_{2} \mathrm{O}\right), 250 \mathrm{~g}$ of urea $\left(\mathrm{CO}\left(\mathrm{NH}_{2}\right)_{2}\right.$; $44 \% \mathrm{~N}), 50 \mathrm{~g}$ of FTE per plant and $13.5 \mathrm{~kg}$ of manure after harvest. Fertilization with $200 \mathrm{~g}$ per plant of calcium nitrate $\left(\mathrm{Ca}\left(\mathrm{NO}_{3}\right)_{2} ; 19 \% \mathrm{Ca}, 14 \% \mathrm{~N}\right)$ and a foliar fertilizer application containing $\mathrm{Ca}$ and $\mathrm{B}(375 \mathrm{ml}$ per $100 \mathrm{~L} \mathrm{H}_{2} \mathrm{O}$ ) were applied during the flowering stage. Potassium nitrate $\left(\mathrm{KNO}_{3} ; 44 \% \mathrm{~K}_{2} \mathrm{O}, 13 \% \mathrm{~N}\right)$ was applied during the fruiting stage. Fertilization need was assessed from soil analysis and nutrient extraction estimated based on the obtained yield. Physical characteristic analysis of the soil was assessed according to EMBRAPA (1997), as described Table 1.

Table 1. Soil physical-hydric attributes of the experimental area.

\begin{tabular}{lcccc}
\hline Parameter & \multicolumn{4}{c}{ Depth $(\mathrm{m})$} \\
\cline { 2 - 4 } & $0,00-0,25$ & $0,25-0,50$ & $0,50-0,75$ & $0,75-1,00$ \\
\hline Sand $\left(\mathrm{g} \mathrm{kg}^{-1}\right)$ & 600 & 770 & 800 & 760 \\
Silt $\left(\mathrm{g} \mathrm{kg}^{-1}\right)$ & 240 & 150 & 120 & 160 \\
Clay $\left(\mathrm{g} \mathrm{kg}^{-1}\right)$ & 160 & 80 & 80 & 80 \\
Water content at $10 \mathrm{kPa}\left(\mathrm{kg} \mathrm{kg}^{-1}\right)$ & 0,23 & 0,16 & 0,14 & 0,16 \\
Water content at $1500 \mathrm{kPa}\left(\mathrm{kg} \mathrm{kg}^{-1}\right)$ & 0,12 & 0,07 & 0,06 & 0,07 \\
\hline
\end{tabular}

After pruning, irrigation management was conducted daily until the plant reach the second vegetative shoot. The mango growth was interrupted by applying the growth regulator Paclobutrazol (PBZ) at $1 \mathrm{~g}$ of the active ingredient per meter of canopy diameter (MOUCO; ALBUQUERQUE, $2005)$. The irrigation remained full $(100 \%$ of ETc) for 15 days, time required for the plant absorb the product. After ceased the irrigation and the plants showed symptoms, such as bending of the tipping branches and shriveling leaves, an application of calcium nitrate $(3 \%)$ was performed. Three sprays were carried out in seven-day intervals aiming to overcome the bud dormancy, started thirty days after the PBZ application, inducing a uniform flowering.

The RDI and PRD treatments were applied from flowering to fruit maturation in three development stages: Stage 1 - early flowering to fruit set, about 65 days after the beginning of flowering;
Stage 2 - fruit development, about 65 to 95 days after the beginning of flowering; and Stage 3 - end of growth and fruit physiological maturity, from 95 to about 120 days after the beginning of flowering. The PRD system was operated for 15 days with a lateral irrigation in one side of the plant row, then interrupted and the other side was irrigated. This alternation was performed from the beginning of flowering to the harvest for all treatments.

A randomized block design was used on seven treatments and six blocks for the RDI experiment: FI - full irrigation in all fruit developmental stages, $100 \%$ ETc; RDI50S1 - full irrigation, $100 \%$ of ETc in stages II and III and 50\% of ETc in stage I; RDI50S2 - full irrigation, $100 \%$ of ETc in stages I and III and $50 \%$ of ETc in stage II; RDI50S3 - full irrigation, $100 \%$ of ETc in stages I and II and $50 \%$ of ETc in stage III; RDI75S1 - full irrigation, $100 \%$ of ETc in stage II and III and $75 \%$ 
of ETc in stage I; RDI75S2 - full irrigation, $100 \%$ ETc in stages I and III and $75 \%$ of ETc in stage II; and RDI75S3 - full irrigation, 100\% ETc in stages I and II and $75 \%$ of ETc in stage III; and with five treatments and six blocks for the PRD experiment: FI - full irrigation, $100 \%$ of ETc, using the conventional drip method; PRD100 - full irrigation, $100 \%$ of ETc; PRD $80-80 \%$ of ETc; PRD60 - 60\% of ETc; and PRD40 - 40\% of ETc. The PRD100, PRD80, PRD60 and PRD40 were conducted alternating the irrigated side every 15 days from flowering to harvest. The experimental plot consisted of one plant in both experiments.

The irrigation was based on the crop evapotranspiration (ETc), which considered the reference evapotranspiration (ETo), the crop coefficient $(\mathrm{Kc})$ and location coefficient values $(\mathrm{Kl})$. The KI unit value was calculated according to the area shaded by the plant. There was no precipitation occurrence in the evaluation period.

The reference evapotranspiration was indirectly found by the Penman-Monteith method, using the FAO Bulletin 56 standard (ALLEN et al., 1998), based on data from a local weather station located near the experimental area. The solar radiation values were estimated by the Hargreaves equation (ALLEN et al., 1998) due to the lack of actual insolation data. This equation considers the maximum and minimum temperature, solar radiation at the top of the atmosphere and the kRs factor, which considers the location.

The Kc values, used to calculate the crop evapotranspiration during the evaluated stages, were 0.62 to 0.87 , according to Cotrim et al. (2011). This method considers the number of days after flowering to find the crop coefficient. The orchard irrigation management during the experiments and irrigation time per day was conducted according to Cotrim et al. (2011), Santos et al. (2013, 2014a, 2014b) and Santos and Martinez (2013).

The fruits were harvested, selected by treatment, counted and weighed. The total yield and fruit number of each treatment were compared. The water use efficiency was found according to Silva et al. (2009), and Santos et al. (2014b) for all treatments, considering the yield and the gross water depth applied.

The physiological variables were evaluated with an infrared gas analyzer (IRGA), model Lcpro $^{+\circledR}$ Portable Photosynthesis System (ADC BioScientific Limited, UK), with ambient temperature and irradiance and air flow of $200 \mathrm{ml}$ $\mathrm{min}^{-1}$. The performed evaluations were photosynthetically active radiation (Qleaf) $\left(\mu \mathrm{mol} \mathrm{m} \mathrm{m}^{-2}\right.$ $\mathrm{s}^{-1}$ of photons), leaf temperature $(\mathrm{Tl})\left({ }^{\circ} \mathrm{C}\right), \mathrm{CO}_{2}$ internal concentration $(\mathrm{Ci})\left(\mu \mathrm{mol} \mathrm{mol}{ }^{-1}\right)$, stomatal conductance $(g s)\left(\mathrm{mol} \mathrm{m} \mathrm{m}^{-2} \mathrm{~s}^{-1}\right)$, transpiration $(E)$ $\left(\mathrm{mmol} \mathrm{m} \mathrm{s}^{-2} \mathrm{~s}^{-1}\right.$ of $\left.\mathrm{H}_{2} \mathrm{O}\right)$, net photosynthesis $(A)(\mu \mathrm{mol}$ $\mathrm{m}^{-2} \mathrm{~s}^{-1}$ of $\mathrm{CO}_{2}$ ), instantaneous water use efficiency $(A / E)$, carboxylation efficiency $(A / C i)$ and quantum efficiency of photosynthesis (A/Qleaf). The PRD experiment had evaluations performed 51, 78, 101 and 143 days after flowering, and the RDI experiment, 53 (Stage I), 82 (Stage II), 107 (Stage II), and 136 (Stage III) days after flowering, both at 8:00 and 14:00h because the contrasting conditions, constituting four evaluations and two time-of-day. Gas exchange evaluations were performed in the central part of intact leaves from the middle of the terminal branch, at a medium height of the tree canopy on the plant side exposed to the sun.

The evaluation of physiological variables was performed by arranged the treatments in a factorial scheme $7 \times 4 \times 2$ for RDI and $5 \times 4 \times 2$ for PRD, both with three replications, in which 7 and 5 were the respective irrigation treatments, 4 was the evaluation times and 2 was the reading hour with the IRGA. The data on fruits number, yield, water use efficiency and physiological characteristics were subjected to analysis of variance. Means were compared using the Tukey test at 5\% probability. The physiological variables were correlated with each other and correlation matrices were generated for the RDI and PRD experiments.

\section{RESULTS AND DISCUSSION}

The irrigation water depths applied to the different treatments and experiments are shown in Figure 2. The RDI with water depth of $75 \%$ of ETc are not shown in Figure $2 \mathrm{~B}$, since these lines are between the full irrigation $(F I)$ and the RDI with $50 \%$ of ETc (RDI50). Treatments were applied 10 days after flowering and ended 142 days after full flowering. 

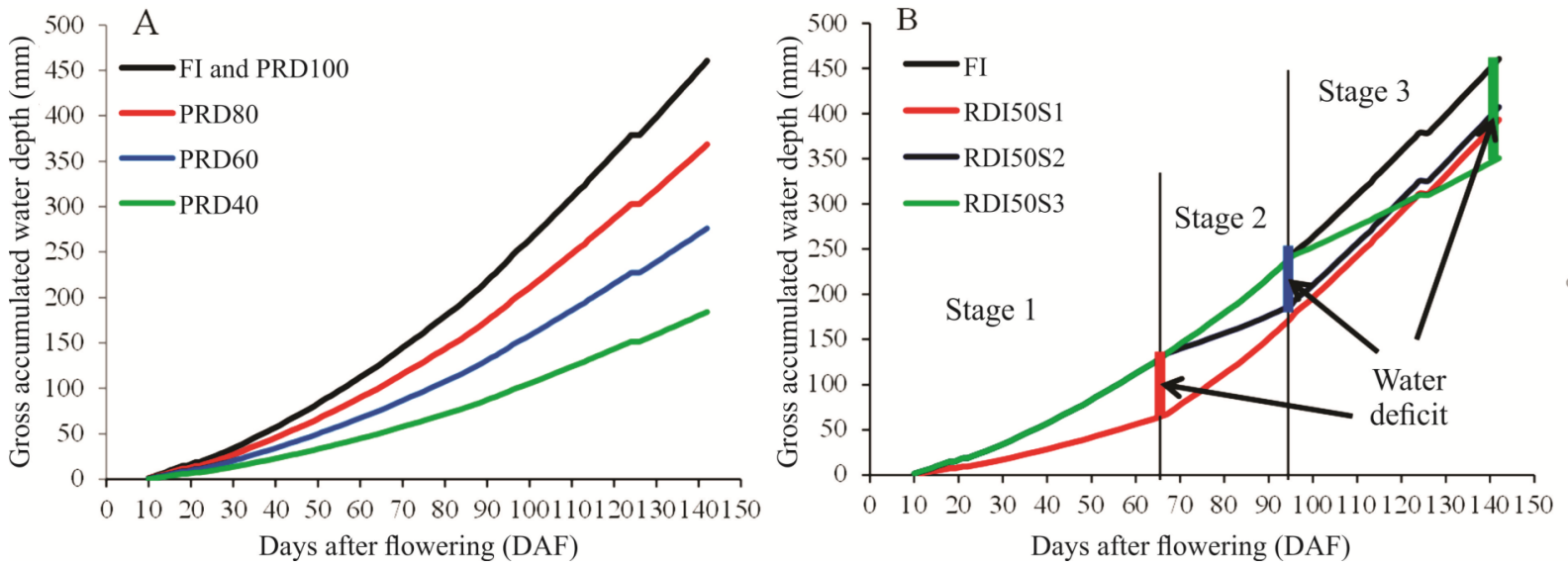

Figure 2. Gross accumulated water depths in the PRD (A) and RDI (B) experiments.

\section{Physiological parameters}

The Photosynthesis, carboxylation efficiency, quantum efficiency of photosynthesis, transpiration, instantaneous water use efficiency and leaf temperature of the 'Tommy Atkins' mango were influenced by the interaction between the time-ofday and evaluation time in the RDI experiment (Table 2). A drop in values of $A, A / C i, A /$ Qleaf, $A / E$ was verified from 53 to 136 days after flowering, with higher values at $8: 00 \mathrm{~h}$. On the other hand, the leaf temperature and transpiration increased with time after flowering (DAF), with higher values at 14:00h.

The photosynthesis $(A)$, transpiration $(E)$, instantaneous water use efficiency $(A / E)$, leaf temperature $(T l)$ and stomatal conductance $(g s)$ of the 'Tommy Atkins' mango were influenced by the interaction between the time-of-day and evaluation time (Table 2) in the PRD experiment.

The higher leaf temperature $\left(39.67^{\circ} \mathrm{C}\right)$ at $14: 00 \mathrm{~h}$ in September contributed to decrease the instantaneous water use efficiency and increased transpiration (Table 4). The photosynthetic rate had the lowest value at 143 DAF (Table 2), which may be related to the low values of stomatal conductance (Table 4). An increase in temperature modifies the rubisco kinetic constants and increases oxygenation rate instead the carboxylation, increases photorespiration and decreases net photosynthesis under ambient $\mathrm{CO}_{2}$ concentration (TAIZ; ZEIGER, 2013). Values above $30^{\circ} \mathrm{C}$, as found in the present study, cause drop in photosynthesis, since the photosynthesis reactions has a Q10 of approximately 2 between 12 and $30^{\circ} \mathrm{C}$ (MEDINA et al., 2005).

The $\mathrm{CO}_{2}$ internal concentration and stomatal conductance ( $g s)$ in RDI had independent effects only for the time-of-day (Table 3) and evaluations times (Table 4) probably due to the effect of higher temperatures at 14 hours and with the increase of DAF (Figure 1). The increase in air temperature may cause an increase in leaf temperature, causing a decrease in the instantaneous water use efficiency $(A / E)$. The increase in leaf temperature causes a decreased in stomatal conductance, carboxylation efficiency, quantum efficiency of photosynthesis and photosynthesis, since there is high correlation between $T l$ and $A / E, g s$ and $A, g s$ and $A / C i$ and $g_{s}$ and A/Qleaf (Table 5). Donato et al. (2013) emphasize that the decrease in the ratio $A / E$ is related to the increase in temperature, even with an increased water depth irrigation up to $125 \%$ of ETc.

Regardless of irrigation strategy and evaluation times, $\mathrm{CO}_{2}$ internal concentration $(\mathrm{Ci})$, carboxylation efficiency $(\mathrm{A} / \mathrm{Ci})$ and quantum efficiency of photosynthesis (A/Qleaf) in the PRD, and the $\mathrm{CO}_{2}$ internal concentration $(\mathrm{Ci})$ and stomatal conductance $(g s)$ in the RDI, were lower at the 14:00h evaluations (Table 3), which can be explained by the increase in leaf temperature.

Regardless of irrigation and evaluation times, $\mathrm{CO}_{2}$ internal concentration was higher at $101 \mathrm{DAF}$ in PRD (Table 4), which may be explained by the higher leaf temperatures on that day $\left(39.67^{\circ} \mathrm{C}\right)$ (Table 2), while the quantum efficiency of photosynthesis was higher at $143 \mathrm{DAF}$, which may be explained by the lower photosynthetically active radiation in that evaluation (Table 4). The stomatal conductance was lower at 136 DAF in RDI (Table 4 ), possibly due to the higher leaf temperature during that day $\left(40.15^{\circ} \mathrm{C}\right.$ at $8: 00 \mathrm{~h}$ and $42.79^{\circ} \mathrm{C}$ at $\left.14: 00 \mathrm{~h}\right)$ (Table 2). 
M. R. DOS SANTOS et al.

Table 2. Photosynthesis $(A)$, carboxylation efficiency $(A / C i)$; quantum efficiency of photosynthesis $(A /$ Qleaf $)$, transpiration $(E)$, instantaneous water use efficiency $(A / E)$, leaf temperature $(T l)$, stomatal conductance $(g s)$ and photosynthetically active radiation (Qleaf) of 'Tommy Atkins' mango at different days after flowering (DAF) and time-of-day, with regulated deficit irrigation (RDI) and partial root-zone drying (PRD).

\begin{tabular}{|c|c|c|c|c|c|c|c|c|}
\hline \multirow{3}{*}{ Parameter } & \multicolumn{4}{|c|}{ RDI } & \multicolumn{4}{|c|}{ PRD } \\
\hline & \multirow[b]{2}{*}{ DAF } & \multicolumn{2}{|c|}{ Time-of-Day } & \multirow{2}{*}{ CV (\%) } & \multirow[b]{2}{*}{ DAF } & \multicolumn{2}{|c|}{ Time-of-Day } & \multirow{2}{*}{$\mathrm{CV}$} \\
\hline & & 08:00 & $14: 00$ & & & 08:00 & $14: 00$ & \\
\hline \multirow{4}{*}{$A$} & 53 & $11,19 \mathrm{Aa}$ & $6,09 \mathrm{Ab}$ & \multirow{4}{*}{33,32} & 51 & $8,73 \mathrm{Ba}$ & $6,57 \mathrm{ABb}$ & \multirow{4}{*}{33,47} \\
\hline & 82 & $7,84 \mathrm{Ba}$ & $5,87 \mathrm{Ab}$ & & 78 & $9,72 \mathrm{ABa}$ & $7,74 \mathrm{Ab}$ & \\
\hline & 107 & $8,33 \mathrm{Ba}$ & $5,52 \mathrm{Ab}$ & & 101 & $11,94 \mathrm{Aa}$ & $6,20 \mathrm{ABb}$ & \\
\hline & 136 & $7,13 \mathrm{Ba}$ & $4,28 \mathrm{Ab}$ & & 143 & $7,95 \mathrm{Ba}$ & $4,52 \mathrm{Bb}$ & \\
\hline \multirow{4}{*}{$\mathrm{A} / \mathrm{Ci}$} & 53 & $0,045 \mathrm{Aa}$ & $0,026 \mathrm{Ab}$ & \multirow{4}{*}{35,57} & 51 & 0,034 & 0,026 & \multirow{4}{*}{37,02} \\
\hline & 82 & $0,029 \mathrm{Ba}$ & $0,023 \mathrm{ABa}$ & & 78 & 0,039 & 0,031 & \\
\hline & 107 & $0,031 \mathrm{Ba}$ & $0,022 \mathrm{ABb}$ & & 101 & 0,043 & 0,024 & \\
\hline & 136 & $0,027 \mathrm{Ba}$ & $0,017 \mathrm{Bb}$ & & 143 & 0,031 & 0,018 & \\
\hline \multirow{4}{*}{ A/Qleaf } & 53 & $0,0075 \mathrm{Aa}$ & $0,0038 \mathrm{Ab}$ & \multirow{4}{*}{34,56} & 51 & 0,0060 & 0,0042 & \multirow{4}{*}{62,13} \\
\hline & 82 & $0,0050 \mathrm{Ba}$ & $0,0037 \mathrm{Ab}$ & & 78 & 0,0083 & 0,0056 & \\
\hline & 107 & $0,0052 \mathrm{Ba}$ & $0,0038 \mathrm{Ab}$ & & 101 & 0,0079 & 0,0038 & \\
\hline & 136 & $0,0061 \mathrm{Ba}$ & $0,0027 \mathrm{Ab}$ & & 143 & 0,0123 & 0,0094 & \\
\hline \multirow{4}{*}{$E$} & 53 & $4,13 \mathrm{Ba}$ & $3,78 \mathrm{Ba}$ & \multirow{4}{*}{32,34} & 51 & $3,11 \mathrm{Aa}$ & $3,60 \mathrm{Ba}$ & \multirow{4}{*}{34,46} \\
\hline & 82 & $3,99 \mathrm{Bb}$ & $4,95 \mathrm{ABa}$ & & 78 & $3,16 \mathrm{Ab}$ & 5,41Aa & \\
\hline & 107 & $5,17 \mathrm{ABb}$ & $6,12 \mathrm{Aa}$ & & 101 & $3,99 \mathrm{Ab}$ & $5,25 \mathrm{Aa}$ & \\
\hline & 136 & $5,54 \mathrm{Aa}$ & $4,51 \mathrm{Bb}$ & & 143 & $2,98 \mathrm{Aa}$ & $3,36 \mathrm{Ba}$ & \\
\hline \multirow{4}{*}{$A / E$} & 53 & $2,75 \mathrm{Aa}$ & $1,61 \mathrm{Ab}$ & \multirow{4}{*}{19,35} & 51 & $2,85 \mathrm{Aa}$ & $1,90 \mathrm{Ab}$ & \multirow{4}{*}{24,70} \\
\hline & 82 & $1,99 \mathrm{Ba}$ & $1,21 \mathrm{Bb}$ & & 78 & $3,17 \mathrm{Aa}$ & $1,50 \mathrm{ABb}$ & \\
\hline & 107 & $1,68 \mathrm{Ca}$ & $0,95 \mathrm{Cb}$ & & 101 & $2,96 \mathrm{Aa}$ & $1,26 \mathrm{Bb}$ & \\
\hline & 136 & $1,36 \mathrm{Da}$ & $0,99 \mathrm{BCb}$ & & 143 & $2,65 \mathrm{Aa}$ & $1,41 \mathrm{ABb}$ & \\
\hline \multirow{4}{*}{$T l$} & 53 & $32,90 \mathrm{Db}$ & $38,56 \mathrm{Ca}$ & \multirow{4}{*}{3,85} & 51 & $31,81 \mathrm{ABb}$ & $36,20 \mathrm{Ca}$ & \multirow{4}{*}{3,75} \\
\hline & 82 & $34,24 \mathrm{Cb}$ & $40,02 \mathrm{Ba}$ & & 78 & $30,97 \mathrm{Bb}$ & $38,54 \mathrm{ABa}$ & \\
\hline & 107 & $36,54 \mathrm{Bb}$ & $43,59 \mathrm{Aa}$ & & 101 & $31,00 \mathrm{Bb}$ & $39,67 \mathrm{Aa}$ & \\
\hline & 136 & $40,15 \mathrm{Ab}$ & $42,79 \mathrm{Aa}$ & & 143 & $32,56 \mathrm{Ab}$ & $38,30 \mathrm{Ba}$ & \\
\hline & 53 & 0,207 & 0,098 & & 51 & $0,156 \mathrm{Ba}$ & $0,122 \mathrm{ABa}$ & \\
\hline & 82 & 0,166 & 0,118 & & 78 & $0,168 \mathrm{Ba}$ & $0,152 \mathrm{Aa}$ & \\
\hline$g s$ & 107 & 0,194 & 0,112 & 44,54 & 101 & $0,290 \mathrm{Aa}$ & $0,134 \mathrm{ABb}$ & 40,53 \\
\hline & 136 & 0,134 & 0,081 & & 143 & $0,132 \mathrm{Ba}$ & $0,080 \mathrm{Bb}$ & \\
\hline & 53 & $1509,35 \mathrm{Ab}$ & $1600,32 \mathrm{Aa}$ & & 51 & 1465,78 & 1583,18 & \\
\hline & 82 & $1568,30 \mathrm{Aa}$ & $1617,03 \mathrm{Aa}$ & & 78 & 1322,47 & 1445,71 & 2414 \\
\hline Qleaf & 107 & $1595,24 \mathrm{Aa}$ & $1518,87 \mathrm{Aa}$ & 8,45 & 101 & 1548,38 & 1635,93 & 24,14 \\
\hline & 136 & $1176,22 \mathrm{Bb}$ & $1518,87 \mathrm{Aa}$ & & 143 & 903,40 & 714,31 & \\
\hline
\end{tabular}

Means followed by different uppercase letters in the columns and lowercase in the line differ by the Tukey test at $5 \%$ probability.

Table 3. $\mathrm{CO}_{2}$ internal concentration $(\mathrm{Ci})$, carboxylation efficiency $(\mathrm{A} / \mathrm{C} i)$, quantum efficiency of photosynthesis $(\mathrm{A} / \mathrm{Qleaf})$ and stomatal conductance $(g s)$ in 'Tommy Atkins' mango under regulated deficit irrigation (RDI) and partial root-zone drying (PRD), evaluated at two time-of-day.

\begin{tabular}{ccccc}
\hline \multirow{2}{*}{ Physiological Variable } & \multicolumn{3}{c}{ PRD } & \multicolumn{2}{c}{ Time-of-Day } \\
\cline { 2 - 5 } & $08: 00 \mathrm{~h}$ & $14: 00 \mathrm{~h}$ & $08: 00 \mathrm{~h}$ & $14: 00 \mathrm{~h}$ \\
\cline { 2 - 5 } & $265,36 \mathrm{~A}$ & $255,35 \mathrm{~B}$ & $263,34 \mathrm{~A}$ & $247,67 \mathrm{~B}$ \\
$C i$ & $0,0368 \mathrm{~A}$ & $0,0248 \mathrm{~B}$ & 0,0333 & 0,0223 \\
$A / C i$ & $0,0086 \mathrm{~A}$ & $0,0057 \mathrm{~B}$ & 0,0060 & 0,0035 \\
$A /$ Qleaf & 0,1866 & 0,1221 & $0,1753 \mathrm{~A}$ & $0,1023 \mathrm{~B}$ \\
\hline$g S$ &
\end{tabular}

Means with different letters in the lines differ by the Tukey test at $5 \%$ probability. 
Table 4. $\mathrm{CO}_{2}$ internal concentration $(\mathrm{Ci})$ and stomatal conductance $(g s)$ under regulated deficit irrigation $(\mathrm{RDI})$, and $\mathrm{CO}_{2}$ internal concentration $(C i)$, carboxylation efficiency $(A / C i)$, quantum efficiency of photosynthesis $(A /$ Qleaf $)$ and photosynthetically active radiation (Qleaf) under partial root-zone drying (PRD) at different evaluation times in 'Tommy Atkins' mango.

\begin{tabular}{|c|c|c|c|c|c|c|c|c|}
\hline \multirow{3}{*}{$\begin{array}{c}\text { Physiological } \\
\text { Variable }\end{array}$} & \multicolumn{5}{|c|}{ PRD } & \multicolumn{2}{|c|}{ RDI } & \\
\hline & \multicolumn{8}{|c|}{ Evaluation time (DAF) } \\
\hline & 51 & 78 & 101 & 143 & 53 & 82 & 107 & 136 \\
\hline $\mathrm{Ci}$ & $258,77 \mathrm{~B}$ & $252,3 \mathrm{~B}$ & $274,34 \mathrm{~A}$ & $256,00 \mathrm{~B}$ & $243,79 \mathrm{~B}$ & $261,94 \mathrm{~A}$ & $259,75 \mathrm{~A}$ & $256,56 \mathrm{~A}$ \\
\hline gs & 0,139 & 0,160 & 0,212 & 0,106 & $0,153 \mathrm{~A}$ & $0,142 \mathrm{AB}$ & $0,153 \mathrm{~A}$ & $0,107 \mathrm{~B}$ \\
\hline$A / C i$ & $0,0299 \mathrm{AB}$ & $0,0349 \mathrm{~A}$ & $0,0334 \mathrm{~A}$ & $0,0249 \mathrm{~B}$ & 0,0357 & 0,0264 & 0,0266 & 0,0224 \\
\hline A/Qleaf & $0,0051 \mathrm{~B}$ & $0,0069 \mathrm{~B}$ & $0,0058 \mathrm{~B}$ & $0,0108 \mathrm{~A}$ & 0,0056 & 0,0043 & 0,0045 & 0,0044 \\
\hline Qleaf & $1525,48 \mathrm{~A}$ & $1384,1 \mathrm{~A}$ & $1592,16 \mathrm{~A}$ & $808,86 \mathrm{~B}$ & 1554,83 & 1592,67 & 1557,06 & 1381,39 \\
\hline
\end{tabular}

Means with different letters in the lines differ by the Tukey test at $5 \%$ probability.

There was a high negative correlation between instantaneous water use efficiency $(A / E)$ and leaf temperature, and a positive correlation between photosynthesis $(A)$ and stomatal conductance $(\mathrm{gs})$, clarboxylation efficiency $(\mathrm{A} / \mathrm{Ci})$ and $g s$, and quantum efficiency of photosynthesis and $g s$, under regulated deficit irrigation (RDI)
(Table 5). There was a high negative correlation between instantaneous water use efficiency $(A / E)$ and leaf temperature, and a positive correlation between photosynthesis $(A)$ and stomatal conductance $(g s)$, and between carboxylation efficiency $(\mathrm{A} / \mathrm{Ci})$ and $g s$ under partial root-zone drying (PRD) (Table 5).

Table 5. Correlation matrix of physiological variables of 'Tommy Atkins' mango under regulated deficit irrigation (RDI) and partial root-zone drying (PRD).

\begin{tabular}{|c|c|c|c|c|c|c|c|c|c|}
\hline \multirow{2}{*}{$\begin{array}{c}\text { Physiological } \\
\text { Variables }\end{array}$} & \multicolumn{9}{|c|}{ RDI } \\
\hline & Qleaf & $T l$ & $c i$ & $E$ & $g_{S}$ & $A$ & $\mathrm{~A} / \mathrm{Ci}$ & A/Qleaf & $A / E$ \\
\hline Qleaf & 1.00 & & & & & & & & \\
\hline$T l$ & -0.06 & 1.00 & & & & & & & \\
\hline$c i$ & -0.02 & -0.41 & 1.00 & & & & & & \\
\hline E & -0.12 & 0.50 & -0.13 & 1.00 & & & & & \\
\hline Gs & -0.02 & -0.34 & 0.19 & 0.57 & 1.00 & & & & \\
\hline$A$ & -0.09 & -0.45 & -0.08 & 0.43 & 0.89 & 1.00 & & & \\
\hline $\mathrm{A} / \mathrm{Ci}$ & -0.09 & -0.37 & -0.26 & 0.41 & 0.81 & 0.98 & 1.00 & & \\
\hline A/Qleaf & -0.40 & -0.39 & -0.07 & 0.43 & 0.82 & 0.95 & 0.93 & 1.00 & \\
\hline$A / E$ & -0.02 & -0.90 & 0.07 & -0.39 & 0.37 & 0.61 & 0.60 & 0.57 & 1.00 \\
\hline \multirow{2}{*}{$\begin{array}{c}\text { Physiological } \\
\text { Variables } \\
\end{array}$} & \multicolumn{9}{|c|}{ PRD } \\
\hline & Qleaf & $T l$ & $c i$ & $E$ & gs & $A$ & $\mathrm{~A} / \mathrm{Ci}$ & A/Qleaf & $A / E$ \\
\hline Qleaf & 1.00 & & & & & & & & \\
\hline$T l$ & 0.02 & 1.00 & & & & & & & \\
\hline $\mathrm{Ci}$ & 0.16 & -0.31 & 1.00 & & & & & & \\
\hline$E$ & 0.20 & 0.58 & -0.09 & 1.00 & & & & & \\
\hline Gs & 0.21 & -0.29 & 0.22 & 0.52 & 1.00 & & & & \\
\hline$A$ & 0.16 & -0.42 & -0.11 & 0.37 & 0.89 & 1.00 & & & \\
\hline$A / C i$ & 0.12 & -0.36 & -0.29 & 0.36 & 0.81 & 0.98 & 1.00 & & \\
\hline A/Qleaf & -0.69 & -0.19 & -0.24 & 0.10 & 0.30 & 0.42 & 0.45 & 1.00 & \\
\hline$A / E$ & 0.02 & -0.87 & -0.07 & -0.39 & 0.41 & 0.66 & 0.66 & 0.31 & 1.00 \\
\hline
\end{tabular}

The irrigation affected only the leaf temperature and the instantaneous water use efficiency in the RDI (Table 6). The RDI with $75 \%$ of ETc, applied during the fruit development stage (RDI75S2), contributed to a lower leaf temperature and hence higher instantaneous water use efficiency.

These values are averages of evaluations from four different days after flowering and in two time-of -day, therefore, there might be some compensation, such as favorable conditions for this treatment, since the evaluations performed by IRGA are specific and vary with environmental conditions, weather and soil moisture at the evaluation time, thus not reflecting faithfully the history experienced by the plant
(SANTOS et al., 2013).

The PRD irrigation treatments was affected by leaf temperature, stomatal conductance, photosynthesis, carboxylation efficiency and instantaneous water use efficiency (Table 6). The means of the PRD treatments had no difference than the full irrigation (FI) treatment means, however, under PRD40 there was a reduction in stomatal conductance, photosynthesis and the carboxylation efficiency. Despite a drop in photosynthesis, the means of the PRD treatments had no difference than the full irrigation regarding the instantaneous water use efficiency $(A / E)$, which may be explained by the drop in the absolute values of transpiration 
(Figure 3) with a reduced water application in the PRD. Santos et al. (2015) reported that the stomatal conductance, transpiration and photosynthesis tend to decreased with an increase in the deficit up to $40 \%$ of ETc in PRD, confirming the results found in the present work.

Table 6. Leaf temperature $(T l)$, stomatal conductance $(g s)$, photosynthesis $(A)$, carboxylation efficiency $(A / C i)$ and instantaneous water use efficiency $(A / E)$ of 'Tommy Atkins' mango under regulated deficit irrigation (RDI) and partial rootzone drying $(\mathrm{PRD})$.

\begin{tabular}{cccccc}
\hline \multirow{2}{*}{ Irrigation } & \multicolumn{5}{c}{ Physiological Variables } \\
\cline { 2 - 6 } & \multicolumn{1}{c}{$g s$} & $A$ & $A / C i$ & $A / E$ \\
\hline FI & $34,71 \mathrm{AB}$ & $0,192 \mathrm{~A}$ & $9,50 \mathrm{~A}$ & $0,037 \mathrm{~A}$ & $2,35 \mathrm{AB}$ \\
PRD100 & $35,09 \mathrm{~A}$ & $0,148 \mathrm{AB}$ & $7,59 \mathrm{AB}$ & $0,030 \mathrm{AB}$ & $2,11 \mathrm{AB}$ \\
PRD80 & $35,26 \mathrm{~A}$ & $0,144 \mathrm{AB}$ & $7,12 \mathrm{~B}$ & $0,027 \mathrm{~B}$ & $2,01 \mathrm{~B}$ \\
PRD60 & $33,95 \mathrm{~B}$ & $0,168 \mathrm{AB}$ & $8,73 \mathrm{AB}$ & $0,033 \mathrm{AB}$ & $2,51 \mathrm{~A}$ \\
PRD40 & $35,40 \mathrm{~A}$ & $0,120 \mathrm{~B}$ & $6,67 \mathrm{~B}$ & $0,027 \mathrm{~B}$ & $2,08 \mathrm{AB}$ \\
\hline FI & $38,56 \mathrm{~A}$ & 0,141 & 6,828 & 0,027 & $1,50 \mathrm{~B}$ \\
RDI50S1 & $38,83 \mathrm{~A}$ & 0,124 & 6,793 & 0,027 & $1,57 \mathrm{AB}$ \\
RDI50S2 & $38,89 \mathrm{~A}$ & 0,133 & 6,536 & 0,025 & $1,43 \mathrm{~B}$ \\
RDI50S3 & $39,37 \mathrm{~A}$ & 0,145 & 7,185 & 0,029 & $1,51 \mathrm{~B}$ \\
RDI75S1 & $39,31 \mathrm{~A}$ & 0,147 & 7,309 & 0,029 & $1,48 \mathrm{~B}$ \\
RDI75S2 & $37,11 \mathrm{~B}$ & 0,128 & 6,914 & 0,027 & $1,83 \mathrm{~A}$ \\
RDI75S3 & $38,14 \mathrm{AB}$ & 0,152 & 7,663 & 0,030 & $1,65 \mathrm{AB}$ \\
\hline
\end{tabular}

Means with different letters in the columns differ by the Tukey test at $5 \%$ probability.
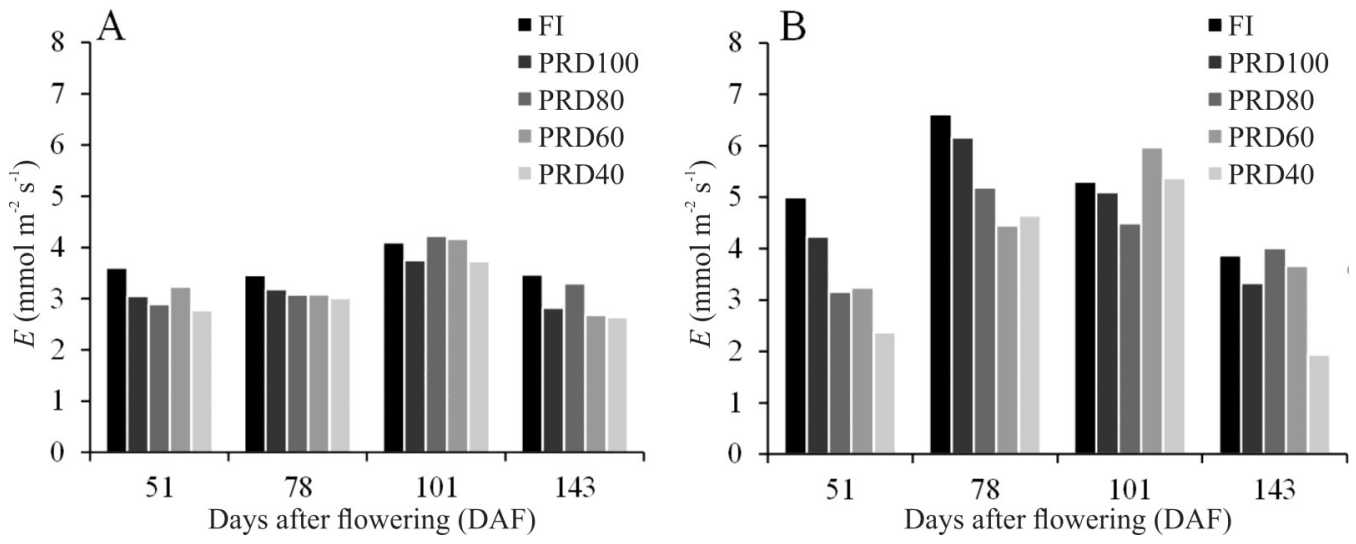

Figure 3. Transpiration $(E)$ of 'Tommy Atkins' mango leaves under partial root-zone drying (PRD) irrigation at 8:00h (A) and 14:00h (B).

\section{Production and water use efficiency}

The PRD irrigation with 80,60 and $40 \%$ of ETc caused a reduction in the 'Tommy Atkins' mango production compared to the full irrigation (FI), and the PRD with $80 \%$ of ETc led to a lower water use efficiency (Table 7). There were deficit effects with PRD between $50 \%$ and $75 \%$ of ETc, applied at different production stages, however, presenting no effect in the water use efficiency (Table 7).

The application of RDI with $50 \%$ of ETc at the fruit set and development stages caused a drop in production, while the RDI with $75 \%$ of ETc caused a reduction in production when applied only to the fruit set stage. This result indicates that the RDI applied to the fruit set and maturation stages is an option to use in mango for reduce the applied water depth while maintaining the yield and maintaining or increasing the water use efficiency. Similar results were found by Santos et al. (2014b) with the application of RDI with $50 \%$ of ETc in 'Tommy
Atkins' mango at fruit development and maturation stages, observing no yield reduction, which enabled to maintain the water use efficiency with RDI applied at fruit development stage (Stage II) and increased water use efficiency in the fruit maturation stage.

The yield in the present work tended to be greater when the deficit was applied at maturation and lower when applied to the fruit set stage, even with no difference between the yields considering only RDI, confirming the results from Santos et al. (2014b), who applied a RDI of $50 \%$ of ETc at the fruit set stage and observed a decreased in yield for two consecutive cycles.

In northern Thailand, Spreer et al. (2007) found no significant reduction in production and fruit quality of 'Chok Anan' mango and stated that it is possible to obtain a sustainable production using PRD with $50 \%$ of ETc. Spreer et al. (2009) stated that a deficit irrigation of 30 to $50 \%$ results in high use efficiency of great savings of water in 'Chok Anan' mango. Sant'Ana et al. (2009) working with 
PRD in a 'Kent' mango orchard in the semi-arid region of the State of Bahia, Brazil, found that the application of $50 \%$ of the water volume does not cause significant yield reductions, with PRD alternating every 14 or 21 days. A PRD with $40 \%$ of ETc, alternating the irrigation side every 15 days, also maintained the yield and increased water use efficiency in 'Tommy Atkins' mango in a semiarid region, according to Santos et al. (2015). The production results of the present work with PRD differs from those found by Spreer et al. (2007), Spreer et al. (2009), Sant'Ana et al. (2009) and Santos et al. (2015). It is noteworthy that each variety have different production patterns and the mango has an alternating production due to end of plant nutrients or by successive deficit applications, as performed in this work.

Table 7. Number of fruits per hectare, yield and water use efficiency (WUE) under regulated deficit irrigation (RDI) and partial root-zone drying (PRD) in 'Tommy Atkins' mango.

\begin{tabular}{lccc}
\hline Irrigation & Number of fruits ha $^{-1}$ & Yield $(\mathrm{t} \mathrm{ha}$ & -1 \\
FI & $46531,25 \mathrm{~A}$ & $21,90 \mathrm{~A}$ & $\left.\mathrm{WUE}^{-1} \mathrm{~kg} \mathrm{~h}^{-1} \mathrm{~mm}^{-1}\right)$ \\
RDI50S1 & $29000,00 \mathrm{~B}$ & $13,10 \mathrm{~B}$ & 47,56 \\
RDI50S2 & $29500,00 \mathrm{~B}$ & $14,28 \mathrm{~B}$ & 33,31 \\
RDI50S3 & $35468,75 \mathrm{AB}$ & $16,57 \mathrm{AB}$ & 35,05 \\
RDI75S1 & $27187,50 \mathrm{~B}$ & $13,78 \mathrm{~B}$ & 47,25 \\
RDI75S2 & $36625,00 \mathrm{AB}$ & $15,63 \mathrm{AB}$ & 32,28 \\
RDI75S3 & $32875,00 \mathrm{AB}$ & $16,12 \mathrm{AB}$ & 36,02 \\
\hline CV (\%) & 54,43 & 54,15 & 39,75 \\
\hline FI & $32187,50 \mathrm{~A}$ & $16,68 \mathrm{~A}$ & 55,17 \\
PRD100 & $27406,25 \mathrm{AB}$ & $14,31 \mathrm{AB}$ & $36,23 \mathrm{~A}$ \\
PRD80 & $9,21 \mathrm{~B}$ & $31,08 \mathrm{AB}$ \\
PRD60 & $18083,33 \mathrm{AB}$ & $8,16 \mathrm{~B}$ & $24,99 \mathrm{~B}$ \\
PRD40 & $15625,00 \mathrm{~B}$ & $7,60 \mathrm{~B}$ & $29,55 \mathrm{AB}$ \\
\hline CV(\%) & $15600,00 \mathrm{~B}$ & 29,04 & $41,28 \mathrm{~A}$ \\
\hline
\end{tabular}

Means followed by different letters in the columns differ by the Tukey test at $5 \%$ probability.

\section{CONCLUSIONS}

Regulated deficit irrigation (RDI) with 75 or $50 \%$ of ETc in any of the fruit development stages does not cause changes in gas exchange, maintain the water use efficiency and, when applied at the fruit set stage reduces yield compared to a full irrigation.

Partial root-zone drying (PRD) with $40 \%$ of ETc causes a reduction in stomatal conductance, photosynthesis and carboxylation efficiencies, and reduces the yield of 'Tommy Atkins' mango compared to a full irrigation.

Climate factors affect the gas exchange and leaf temperature of 'Tommy Atkins' mango more than the partial deficit of $50 \%$ of ETc with regulated deficit irrigation.

\section{REFERENCES}

ALLEN, R.G. et al. Crop evapotranspiration: guidelines for computing crop water requirements. Rome: FAO, 1998. 300 p. (FAO. Irrigation and Drainage Paper, 56).

BASSOI, L. H. et al. Influência de manejos de irrigação sobre aspectos de ecofisiologia e de produção da videira cv. Syrah/Paulsen 1103. Irriga, Botucatu, v. 16, n. 4, p. 395-402, 2011.
COTRIM, C. E. et al. Regulated deficit irrigation and 'Tommy Atkins' mango orchard productivity under microsprinkling in Brazilian semiarid. Engenharia Agrícola, Jaboticabal, v. 31, n. 6, p. 1052-1053, 2011.

DONATO, S. L. R.. et al. Ecofisiologia e eficiência de uso da água em bananeira. In: REUNIÃO INTERNACIONAL DA ASSOCIAÇÃO PARA A COOPERAÇÃO EM PESQUISA E DESENVOLVIMENTO INTEGRAL DAS MUSÁCEAS (BANANAS E PLÁTANOS), 20., 2013, Fortaleza. Anais... Fortaleza: ACORBAT, 2013. p. 58-72.

EMBRAPA. Embrapa Semi-Árido. Sistema de Produção, 2. Cultivo da Mangueira. Disponível em: $<\quad$ https://sistemasdeproducao.cnptia.embrapa.br/ FontesHTML/Manga/CultivodaMangueira_2ed/> Acesso em: 04 mar. 2014.

EMBRAPA. Manual de métodos de análise de solo. 2. ed. Rio de Janeiro, RJ: EMBRAPA-CNPS, 1997. $212 \mathrm{p}$.

EMBRAPA. Sistema Brasileiro de Classificação de Solos. 3. ed. rev. ampl. Brasília, DF: EMBRAPA, 2013. 353 p.

GHRAB, M. et al. Long-term effects of partial rootzone drying (PRD) on yield, oil composition and 
quality of olive tree (cv. Chemlali) irrigated with saline water in arid land. Journal of Food Composition and Analysis, New York, v. 36, n. 1, p. 90-97, 2014.

IBGE - Instituto Brasileiro de Geografia e Estatística. Disponível em: <http://www.ibge.gov.br/ estadosat/temas.php?

sigla $=$ ba\&tema $=$ lavourapermanente $>$ Acesso: mar. 2014.

IPCC. Intergovernmental Panel on Climate Change, 2000. Disponível em: $<$ http://www.ipcc.ch/ $\mathrm{pdf} /$ special-reports/spm/sres-sp.pdf $>$. Acesso em: 22 set. 2014

LIMA, R .S. M. et al. Partial rootzone drying (PRD) and regulated deficit irrigation (RDI) effects on stomatal conductance, growth, photosynthetic capacity, and water-use efficiency of papaya. Scientia Horticulturae, Netherlands, v. 183, n. 1, p. 13-22, 2015.

McCARTHY, M. G et al. Regulated deficit irrigation and partial root zone drying as irrigation management techniques for grape vines. In. Deficit Irrigation Practices, Water Reports. Roma: FAO, 2000. n. 22 , p. $79-87$.

MEDINA, C. L. et al. Fisiologia dos citros. In: MATTOS JÚNIOR, D. et al. (Ed.). Citros. Campinas: IAC, 2005. p.147-195.

MOUCO. M. A. C.; ALBUQUERQUE, J. A. S. Efeito do Paclobutrazol em duas épocas de produção da mangueira, Bragantia, Campinas, v. 4, n. 2, p. 219-225, 2005.

OLIVEIRA, E. C. et al. Effects of water deficit in two phenological stages on production of japanese cucumber cultived in greenhouse. Engenharia Agrícola, Jaboticabal, v. 31, n. 4, p. 676-686, 2011.

ROMERO-CONDE, A.; KUSAKABE, A.; MELGAR, J. C. Physiological responses of citrus to partial rootzone drying irrigation. Scientia Horticulturae, Netherlands, v. 169, n.1, p. 234-238, 2014.

SAMPAIO, A. H. R. et al. Indicadores fisiológicos da lima ácida tahiti submetida à irrigação deficitária com secamento parcial de raiz. Irriga, Botucatu, v. 19, n. 2, p. 292-301, 2014

SAMPAIO, A. H. R. et al. Déficit hídrico e secamento parcial do sistema radicular em pomar de lima ácida. Pesquisa Agropecuária Brasileira, Brasília, v. 45, n. 10, p. 1141-1148, 2010.
COElHO, E. F.; ALVES, A. A. C.; OLIVEIRA, V. V. M.; VELAME, L. M. Manejo de irrigação com déficit (PRD) em pomar de manga 'Kent' no semiárido baiano. In: JORNADA CIENTÍFICA, 3., 2009, Cruz das Almas. Anais... Cruz das Almas: EMBRAPA MANDIOCA E FRUTICULTURA. 2009. 1 CD-ROM.

SANTOS, M. R.; MARTINEZ, M. A. Soil water distribution and extraction by 'Tommy Atkins' mango (Mangifera indica L.) trees under different irrigation regimes. Idesia, Arica, v. 31, n. 3, p. 7-16, 2013

SANTOS, M. R.; MARTINEZ, M. A.; DONATO, S. L. R. Gas exchanges of Tommy Atkins mango trees under different irrigation treatments. Bioscience Journal, Uberlândia, v. 29, n. 5, p. 1141-1153, 2013.

SANTOS, M. R. et al. Fruit yield and root system distribution of 'Tommy Atkins' mango under different irrigation regimes. Revista Brasileira de Engenharia Agrícola e Ambiental, Campina Grande, v. 18, n. 4, p. 362-369, 2014a.

SANTOS, M. R. et al. Tommy Atkins mango yield and photosynthesis under hydric deficit in semiarid region of Bahia. Revista Brasileira de Engenharia Agrícola e Ambiental, Campina Grande, v. 18, n. 9 , p. $899-907,2014$ b.

SANTOS, M. R. et al. Yield, Water Use Efficiency and Physiological Characteristic of "Tommy Atkins" Mango under Partial Rootzone Drying Irrigation System. Journal of Water Resource and Protection, Wuhan, v. 7, n. 13, p. 1029-1037. 2015.

SPREER, W. et al. Effect of regulated deficit irrigation and partial rootzone drying on the quality of mango fruits (Mangifera indica L., cv. 'Chok Anan'). Agricultural water management, Amsterdam, v. 88, n. 1, p. 173-180, 2007.

SPREER, W. et al. Yield and fruit development in mango (Mangifera indica L. cv. Chok Anan) under different irrigation regimes. Agricultural water management, Amsterdam, v. 96, n. 1, p. 574-584, 2009.

TAIZ, L.; ZEIGER, E. Fisiologia vegetal. 5. ed. Porto Alegre, RS: ARTMED, 2013. 954 p.

SANT'ANA, J. A. V.; COELHO FILHO, M. A.; 